\title{
Kemandirian Belajar Mahasiswa Melalui Blended Learning Mata Kuliah Kalkulus Lanjut Era Pandemi Covid-19
}

\author{
Ganjar Susilo $^{\left.1^{*}\right)}$, \& Ninda Pancarani ${ }^{2}$ \\ ${ }^{1,2}$ Universitas Balikpapan, Balikpapan, Indonesia
}

\section{INFO ARTICLES}

Article History:

Received: 02-11-2020

Revised: 16-12-2020

Approved: 18-12-2020

Publish Online: 25-12-2020

\section{Key Words:}

Self-Regulated Learning; Blended Learning; Advanced Calculus;

\section{(i) (2)}

BY SA This article is licensed under a Creative Commons AttributionShareAlike 4.0 International License.

\begin{abstract}
This study aims to obtain students' responses and opinions regarding independent learning through blended learning in advanced calculus courses. The type of this research is a qualitative descriptive study. The number of research subjects for the questionnaire in this study was 11 people. From the 11 people involved, 3 people were taken to be interviewed by taking the subject using purposive sampling technique. The finding obtained is the percentage of respondents on student learning independence through blended learning in advanced calculus courses which is 64,0\%. This results indicate that students with good learning independence have creativity and initiative in utilizing learning resources during blended learning. Therefore, they can make their own decisions regarding their duties and responsibilities as learners. Besides, the students can diagnose the final grade (very good or good) obtained by the learning strategies of each student. Furthermore, the existence of blended learning makes students on time in collecting assignments and in following courses using directions given by lectures.
\end{abstract}

\begin{abstract}
Abstrak: Penelitian ini bertujuan untuk memperoleh tanggapan dan pendapat mahasiswa berkaitan dengan kemandirian belajar melalui blended learning pada mata kuliah kalkulus lanjut. Jenis penelitian yang dilakukan adalah penelitian deskriptif kualitatif. Jumlah subjek penelitian untuk angket dalam penelitian ini ada 11 orang, dari 11 orang yang dilibatkan diambil 3 orang untuk diwawancarai dengan cara mengambil subjek yaitu purposive sampling. Temuan yang diperoleh yaitu persentase responden terhadap kemandirian belajar mahasiswa melalui pembelajaran blended learning mata kuliah kalkulus lanjut adalah $64,0 \%$. Hasil tersebut menunjukkan bahwa mahasiswa dengan kemandirian belajar yang baik memiliki kreatifitas dan inisiatif dalam memanfaatkan sumber belajar selama pembelajaran blended learning, mampu membuat keputusannya sendiri berkaitan dengan tugas dan tanggung jawabnya sebagai peserta didik, mahasiswa mampu mendiagnosis nilai akhir (sangat baik atau baik) yang diperoleh dengan strategi belajar masing-masing mahasiswa serta dengan adanya blended learning membuat mahasiswa tepat waktu dalam pengumpulan tugas dan mengikuti pembelajaran sesuai dengan arahan dosen.
\end{abstract}

Correspondence Address: Jln. Pupuk Raya, Balikpapan, 76114, Indonesia; e-mail: ganjar.susilo@uniba-bpn.ac.id

How to Cite (APA $6^{\text {th }}$ Style): Susilo, G., \& Pancarani, N. (2020). Kemandirian Belajar Mahasiswa Melalui Blended Learning Mata Kuliah Kalkulus Lanjut Era Pandemi Covid-19. JKPM (Jurnal Kajian Pendidikan Matematika), 6(1): 37-48.

Copyright: 2020 Ganjar Susilo, Ninda Pancarani

Competing Interests Disclosures: The authors declare that they have no significant competing financial, professional or personal interests that might have influenced the performance or presentation of the work described in this manuscript. 


\section{PENDAHULUAN}

Kegiatan pembelajaran merupakan suatu kegiatan transfer ilmu dari guru atau dosen ke siswa atau mahasiswa. Dalam hal ini kegiatan pengajaran dan pembelajaran tidak harus seorang pendidik sebagai pusat sumber informasi. Peserta didik dapat memperoleh informasi secara mandiri dengan bantuan teknologi yang sudah ada dan semakin canggih seperti mengakses informasi dari internet, buku atau sumber lain. Di mana kegiatan pembelajaran di era sekarang juga tidak hanya dengan tatap muka saja dan berpusat pada pendidik namun bisa melalui kegiatan lain yang dapat dilakukan di waktu yang tidak terikat dengan jadwal yang sudah ditentukan ataupun tempat yang telah disediakan oleh stakeholder seperti kelas dan laboratorium. Hal ini bertujuan untuk mendapatkan pengetahuan dalam belajar dengan memanfaatkan kecanggihan teknologi.

Kemampuan seseorang untuk mengatur atau menyusun semua aktivitas kesehariannya, kompetensi keahliannya, dan kecakapannya dibentuk secara mandiri dengan berbekal kemampuan dasar yang dimilikinya, kegiatan kemampuan proses belajar dan pembelajaran seperti ini disebut dengan kemandirian belajar (Ningsih \& Nurrahmah, 2016). Kemandirian belajar adalah kegiatan belajar tanpa bergantung pada orang lain dalam mencapai tujuan belajar seperti menguasai materi bahan ajar dengan baik serta adanya kesadaran sendiri dalam mengaplikasikan pengetahuannya untuk menyelesaikan masalah dikehidupan sehari-harinya (Syahputra, 2017). Menurut Laksana \& Hadijah (2019) kemandirian belajar merupakan suatu kondisi kegiatan proses belajar yang bertanggung jawab sendiri, tidak bergantung dengan orang lain, memiliki kemampuan yang sadar akan tanggung jawab yang diberikan, dan berinisiatif belajar untuk mendapatkan pengetahuan. Dari definisi yang telah dijelaskan maka dapat diketahui bahwa kemandirian belajar adalah kegiatan atau aktivitas belajar atas kesadaran atau inisiatif seseorang tanpa bergantung dengan orang lain dengan menggunakan kemampuannya sendiri untuk mencapai tujuan belajar tersebut.

Selanjutnya pembelajaran yang mengkombinasikan keunggulan antara metode belajar dan pengajaran konvensional atau tatap muka (face to face) dengan pembelajaran elektronik (e-learning) disebut sebagai model pembelajaran dan pengajaran blended learning (Supandi, Kusumaningsih, \& Aryanto, 2016). Menurut Usman (2018: 138) pengajaran blended learning adalah kegiatan pembelajaran yang menggabungkan pembelajaran yang biasa pendidik lakukan di dalam kelas dengan pembelajaran daring yang memanfaatkan teknologi informasi yang telah ada saat ini. Fandianta, Sanjaya, \& Widyandana (2013) menyatakan bahwa pendekatan pengajaran blended learning membantu para peserta didik untuk menciptakan dan membuat pemahaman bersama tentang konsep-konsep pengetahuan dengan kebiasaan belajar yang memberikan kesempatan untuk memperkuat peserta didik berada dalam suasana kelas yang dinamis.

Berdasarkan observasi peneliti yang dilakukan pada beberapa mahasiswa Universitas Balikpapan pada Tahun Akademik 2019/2020, kondisi pembelajaran dan pengajaran yang awalnya dilaksanakan dengan tatap muka secara langsung berubah menjadi pengajaran blended learning, dimana kegiatan ini berubah sejak mewabahnya pandemi virus corona (Covid-19). Menurut Churiyah, Sholikhan, Filianti, \& Sakdiyyah (2020) dengan mewabahnya Covid-19, Pemerintah Pusat dan Daerah yang ada di Indonesia menganjurkan semua aktivitas perkantoran dan pendidikan terutama untuk pembelajaran dilakukan dari rumah. Hal ini terjadi karena kegiatan yang mengumpulkan massa dibatasi, sehingga perkuliahan pun dilakukan secara daring (dalam jaringan).

Pelaksanaan pembelajaran daring (online) identik dengan pembelajaran secara jarak jauh, dan sistem pembelajaran ini membuat pengajar dan pendidik dalam proses belajar mengajarnya dilaksanakan melalui pemanfaatan teknologi dan informasi secara terstruktur dimana komunikasi atau hubungan peserta didik dengan pengajar atau pendidik dan terjadi secara teratur, substantif, dan mendukung satu sama lainnya (Churiyah et al., 2020; Yuliati \& Saputra, 2020). Adanya pembelajaran ini maka dikampus Universitas 
Balikpapan melakukan kegiatan belajar menggunakan pembelajaran e-learning. Walaupun kegiatan perkuliahan dilakukan secara daring dalam pelaksanaannya tetap tatap muka melalui aplikasi zoom serta penugasan online dari e-learning yang disediakan oleh pihak kampus. Aplikasi zoom merupakan aplikasi untuk video conference secara massa dan mampu menampilkan materi yang sedang dibahas saat perkuliahan berlangsung. Penugasan daring (online) dari e-learning biasanya berupa pemberian tugas dari dosen dengan batas waktu pengerjaan. Karena kondisi ini beberapa mahasiswa mengeluhkan pembelajaran blended learning. Menurut mereka pembelajaran blended learning mengakibatkan kesulitan dalam memahami pembelajaran.

Kesulitan dalam pemahaman pembelajaran ini memiliki hubungan dengan kemandirian belajar dimana sejalan dengan hasil penelitian Mulianty, Hanifa, \& Sugandi (2018: 1071) mengatakan bahwa ada perubahan atau pengaruh hubungan antara kemampuan pemahaman matematika dengan kemandirian belajar mahasiswa dalam pembelajaran matematika yang telah diajarkan di kelas. Kemandirian belajar sendiri memiliki 8 indikator yakni: (1) keinginan dan kesadaran belajar, (2) mampu mengatasi masalah, (3) memiliki kemampuan menentukan nasib sendiri, (4) kreatif dan inisiatif dalam memanfaatkan sumber belajar dan memilih strategi belajar, (5) mampu menahan diri, (6) Mampu bertanggungjawab dengan keputusan sendiri, (7) mendiagnosis kebutuhan belajar, dan (8) memonitor dan mengevaluasi kegiatan belajar (Lestari \& Yudhanegara, 2017: 94).

Banyak peneliti yang tertarik dengan kemandirian belajar melalui blended learning diantaranya penelitian Fitriasari, Tanzimah, \& Sari (2018) mengatakan bahwa terjadi peningkatan kegiatan belajar mengajar yang mendapatkan perlakuan pengajaran blended learning tidak lebih baik daripada mahasiswa yang mendapatkan pembelajaran konvensional, penelitian Aslamiyah, Setyosari, \& Praherdhiono (2019) menunjukkan bahwa dengan menggunakan pengajaran blended learning mahasiswa lebih dimudahkan mencari pengetahuan secara mandiri sehingga bermanfaat dalam proses pembelajarannya. Selain itu pula, Wahyuni \& Nurhayati (2019) juga menunjukkan bahwa persentase responden terhadap kemandirian belajar mahasiswa melalui pengajaran blended learning pada mata kuliah matematika ekonomi sebesar 77,0\%, dan dari hasil tersebut dapat diketahui persentase tanggapan responden berada pada kriteria baik, karena hasil persentase tangapan yang diperoleh berada pada rentang $68,01 \%-84,00 \%$. Oleh karena itu, peneliti tertarik untuk mengetahui tanggapan dan pendapat mahasiswa terhadap kemandirian belajar melalui pengajaran blended learning di proses pembelajaran pada mata kuliah Kalkulus Lanjut.

\section{METODE}

Penelitian ini merupakan penelitian kualitatif bersifat deskriptif, karena penelitian ini merupakan upaya untuk mendeskripsikan tanggapan mahasiswa mengenai kemandirian belajar melalui blended learning. Sugiyono (2017: 8) memaparkan bahwa penelitian kualitatif adalah kegiatan meneliti yang bertujuan untuk memahami fenomena atau kejadian yang dialami oleh subjek seperti, sikap atau perbuatan, pemahaman, dukungan, upaya atau tindakan, dengan cara tersistematis, serta mendeskripsikannya atau menyajikan hasilnya dalam bentuk kalimat dengan bahasa yang logis dan baik, pada suatu konteks khusus yang alamiah dan memanfaatkan atau menggunakan berbagai metode dan kaidah ilmiah yang telah disusun.

Tempat melakukan penelitian berada di Universitas Balikpapan dengan kriteria subjek adalah mahasiswa semester VI (enam) Program Studi Pendidikan Matematika tahun akademik 2019/2020 yang menikuti mata kuliah kalkulus lanjut. Teknik pengambilan subjek penelitian menggunakan teknik purposive sampling yaitu dengan cara, peneliti memberikan angket kemandirian belajar kepada 11 orang yang mengikuti mata kuliah kalkulus lanjut, selanjutnya setelah mengisi angket tersebut dari 11 orang subjek diambil 3 orang dengan kriteria mahasiswa yang mempunyai nilai Indeks Prestasi Kumulatif (IPK) tinggi 
yaitu 3,51-4,00, sedang yaitu 2,76-3,50, dan rendah 2,00-2,75. Beberapa pertimbangan lain yaitu narasumber adalah mahasiswa yang sedang menjalankan perkuliahan dan mudah diwawancarai untuk hasil penelitian yang akurat.

Teknik pengumpulan data pada penelitian ini yaitu angket dan wawancara. Penyebaran angket dilakukan melalui google form. Item angket berupa pernyataan yang memuat 8 indikator kemandirian belajar menurut Lestari \& Yudhanegara (2017: 94). Skala yang digunakan adalah skala likert. Terdapat 20 pernyataan yang menjadi indikator kemandirian belajar mahasiswa dalam menjalakan blended learning, seperti pada Tabel 1.

Tabel 1. Kisi Kisi Angket Kemandirian Belajar

\begin{tabular}{clcc}
\hline \multirow{2}{*}{ No. } & \multicolumn{1}{c}{ Aspek yang Diamati } & Jumlah Butir & No. Butir \\
\hline 1 & Keinginan dan kesadaran (Inisiatif) belajar & 6 & $1,2,3,11,12,13$ \\
2 & Mampu Mengatasi Masalah & 2 & 4,14 \\
3 & Memiliki kemampuan menentukan nasib sendiri & 2 & 5,15 \\
4 & Kreatif dan inisiatif dalam memanfaatkan sumber belajar & 2 & 6,16 \\
5 & dan memilih strategi belajar & 2 & 7,17 \\
6 & Mampu menahan diri & 2 & 8,18 \\
7 & Menpu bertanggungjawab dengan keputusan sendiri & 2 & 9,19 \\
8 & memonitor dan mengevaluasi kegiatan belajar & 2 & 10,20 \\
& $\quad$ Jumlah & 20 & \\
\hline
\end{tabular}

Teknik analisis data pada penelitian menggunakan triangulasi teknik, dengan menganalisis data yang diambil dengan cara mereduksi data, merangkum semua hasil data dan disajikan dalam benuk narasi kemudian diambil simpulan.

\section{HASIL}

Penyajian data dalam penelitian ini didasarkan pada hasil angket. Dari hasil penyajian data kemudian dianalisis untuk mengetahui tanggapan mahasiswa. Skor setiap butir pernyataan positif dengan kriteria sangat setuju (SS), setuju (S), tidak setuju (TS), dan sangat tidak setuju (STS) masing-masing diberi skor berturut-turut 4, 3, 2, dan 1. Sedangkan, skor setiap butir pernyataan negatif dengan kriteria sangat setuju (SS), setuju (S), tidak setuju (TS), dan sangat tidak setuju (STS) masing-masing diberi skor berturut-turut 1, 2, 3, dan 4. Hasil perhitungan persentase pada Tabel 2., memperlihatkan persentase tanggapan atau jawaban dari responden untuk tiap indikator yang telah disusun.

\section{Tabel 2. Indikator Kemandirian Belajar Mahasiswa}

\begin{tabular}{|c|c|c|c|c|c|c|c|c|c|}
\hline \multirow{3}{*}{ No. } & \multirow{3}{*}{ Indikator } & \multicolumn{8}{|c|}{ Tanggapan } \\
\hline & & \multicolumn{4}{|c|}{ Pernyataan Positif } & \multicolumn{4}{|c|}{ Pernyataan Negatif } \\
\hline & & 1 & 2 & 3 & 4 & 1 & 2 & 3 & 4 \\
\hline 1 & $\begin{array}{l}\text { Saya mempelajari materi Kalkulus } \\
\text { Lanjut sebelum pembelajaran } e \text { - } \\
\text { learning berlangsung }\end{array}$ & $0 \%$ & $36 \%$ & $55 \%$ & $0 \%$ & - & - & - & - \\
\hline 2 & $\begin{array}{l}\text { Saya mengulang kembali tugas, atau } \\
\text { tes di rumah untuk dikerjakan }\end{array}$ & $0 \%$ & $45 \%$ & $45 \%$ & $9 \%$ & - & - & - & - \\
\hline
\end{tabular}




\begin{tabular}{|c|c|c|c|c|c|c|c|c|c|}
\hline \multirow{3}{*}{ No. } & \multirow{3}{*}{ Indikator } & \multicolumn{8}{|c|}{ Tanggapan } \\
\hline & & \multicolumn{4}{|c|}{ Pernyataan Positif } & \multicolumn{4}{|c|}{ Pernyataan Negatif } \\
\hline & & 1 & 2 & 3 & 4 & 1 & 2 & 3 & 4 \\
\hline 3 & $\begin{array}{l}\text { Saya mengulang kembali materi } \\
\text { Kalkulus Lanjut di rumah }\end{array}$ & $0 \%$ & $45 \%$ & $55 \%$ & $0 \%$ & - & - & - & - \\
\hline 4 & $\begin{array}{l}\text { Saya mengerjakan tugas Kalkulus } \\
\text { Lanjut dengan referensi belajar lain } \\
\text { (Youtube, Google, atau lainnya) }\end{array}$ & $0 \%$ & $18 \%$ & $27 \%$ & $55 \%$ & - & - & - & - \\
\hline 5 & $\begin{array}{l}\text { Saya yakin mendapat nilai yang sangat } \\
\text { baik pada mata kuliah Kalkulus Lanjut }\end{array}$ & $9 \%$ & $18 \%$ & $36 \%$ & $36 \%$ & - & - & - & - \\
\hline 6 & $\begin{array}{l}\text { Fitur media e-learning dapat } \\
\text { menyimpan bahan ajar dari dosen } \\
\text { sehingga dapat diakses kapan saja }\end{array}$ & $0 \%$ & $0 \%$ & $55 \%$ & $45 \%$ & - & - & - & - \\
\hline 7 & $\begin{array}{l}\text { Saya lebih memperhatikan penjelasan } \\
\text { dosen ketika pembelajaran e-learning } \\
\text { berlangsung }\end{array}$ & $9 \%$ & $0 \%$ & $73 \%$ & $18 \%$ & - & - & - & - \\
\hline 8 & $\begin{array}{l}\text { Dengan pembelajaran e-learning } \\
\text { membuat saya harus mengumpulkan } \\
\text { tugas Kalkulus Lanjut dengan tepat } \\
\text { waktu }\end{array}$ & $0 \%$ & $0 \%$ & $27 \%$ & $73 \%$ & - & - & - & - \\
\hline 9 & $\begin{array}{l}\text { Saya aktif bertanya ketika } \\
\text { pembelajaran } e \text {-learning berlangsung }\end{array}$ & $18 \%$ & $27 \%$ & $55 \%$ & $0 \%$ & - & - & - & - \\
\hline 10 & $\begin{array}{l}\text { Saya belajar mandiri dengan membuat } \\
\text { jadwal }\end{array}$ & $9 \%$ & $45 \%$ & $45 \%$ & $0 \%$ & - & - & - & - \\
\hline 11 & $\begin{array}{l}\text { Saya mempelajari materi Kalkulus } \\
\text { Lanjut saat pembelajaran } e \text {-learning } \\
\text { berlangsung }\end{array}$ & - & - & - & - & $9 \%$ & $64 \%$ & $27 \%$ & $0 \%$ \\
\hline 12 & $\begin{array}{l}\text { Saya mencoba mengerjakan kembali } \\
\text { tugas, atau tes saat pembelajaran }\end{array}$ & - & - & - & - & $9 \%$ & $45 \%$ & $36 \%$ & $9 \%$ \\
\hline 13 & $\begin{array}{l}\text { Saya mengingat kembali materi } \\
\text { Kalkulus Lanjut ketika ditanya oleh } \\
\text { dosen }\end{array}$ & - & - & - & - & $9 \%$ & $55 \%$ & $27 \%$ & $9 \%$ \\
\hline 14 & $\begin{array}{l}\text { Saya mengerjakan tugas dengan } \\
\text { materi Kalkulus Lanjut yang diberikan } \\
\text { oleh dosen melalui E-learning }\end{array}$ & - & - & - & - & $45 \%$ & $55 \%$ & $0 \%$ & $0 \%$ \\
\hline 15 & $\begin{array}{l}\text { Saya yakin mendapat nilai yang baik } \\
\text { pada mata kuliah Kalkulus Lanjut }\end{array}$ & - & - & - & - & $36 \%$ & $36 \%$ & $9 \%$ & $18 \%$ \\
\hline 16 & $\begin{array}{l}\text { Fitur media e-learning hanya bisa } \\
\text { sekali akses }\end{array}$ & - & - & - & - & $0 \%$ & $36 \%$ & $64 \%$ & $0 \%$ \\
\hline 17 & $\begin{array}{l}\text { Saya lebih memperhatikan penjelasan } \\
\text { dosen ketika memutar video rekaman } \\
\text { pembelajaran }\end{array}$ & - & - & - & - & $18 \%$ & $55 \%$ & $27 \%$ & $0 \%$ \\
\hline 18 & $\begin{array}{l}\text { Dengan pembelajaran } e \text {-learning } \\
\text { pengumpulan tugas bisa tidak tepat } \\
\text { waktu }\end{array}$ & - & - & - & - & $0 \%$ & $36 \%$ & $45 \%$ & $18 \%$ \\
\hline
\end{tabular}




\begin{tabular}{llllllllll}
\hline & & \multicolumn{1}{c}{ Tanggapan } \\
No. & \multicolumn{1}{c}{ Indikator } & \multicolumn{1}{c}{ Pernyataan Positif } & \multicolumn{3}{c}{ Pernyataan Negatif } \\
& & 1 & 2 & 3 & 4 & 1 & 2 & 3 & 4 \\
\hline 19 & $\begin{array}{l}\text { Saya malu bertanya ketika } \\
\text { pembelajaran } \text {-learning berlangsung }\end{array}$ & - & - & - & - & $27 \%$ & $27 \%$ & $45 \%$ & $9 \%$ \\
20 & Saya belajar mandiri ketika ada tugas & - & - & - & - & $27 \%$ & $64 \%$ & $9 \%$ & $0 \%$ \\
\hline & Rata Rata & $5 \%$ & $24 \%$ & $47 \%$ & $24 \%$ & $18 \%$ & $47 \%$ & $29 \%$ & $6 \%$ \\
\hline
\end{tabular}

Berdasarkan Tabel 2. dapat diketahui rata-rata persentase tanggapan atau jawaban pernyataan positif dari responden untuk setuju dan sangat setuju lebih besar daripada pilihan jawaban tidak setuju dan sangat tidak setuju. Pada pernyataan negatif, rata-rata persentase jawaban dari responden untuk setuju dan sangat setuju lebih kecil daripada pilihan jawaban tidak setuju dan sangat tidak setuju. Dari hasil tanggapan dua pernyataan positif dan negatif ini menunjukkan hal yang positif.

Persentase tanggapan atau jawaban peserta didik pada anget yang diberikan menunjukkan kemandirian belajar dengan pengajaran blended learning berdasarkan jawaban tanggapan dapat dianalisis untuk persentase skor aktualnya. Skor aktual adalah jawaban seluruh responden atas angket yang telah dianjurkan. Dimana skor aktual dibagi dengan skor ideal dikali 100\%. Skor ideal merupakan skor penilaian tertinggi atau skor penilaian semua responden atau tanggapan yang diberikan dengan mengasumsikan memilih jawaban dengan skor tertinggi. Tabel kriteria persentase skor tanggapan terhadap skor ideal yang disajikan dalam Tabel 3.

Tabel 3. Kriteria Persentase Skor Tanggapan terhadap Skor Ideal

\begin{tabular}{ccc}
\hline No & Persentase Jumlah Skor $(\%)$ & Kriteria \\
\hline 1 & $20,00-36,00$ & Tidak Baik \\
2 & $36,01-52,00$ & Kurang Baik \\
3 & $52,01-68,00$ & Cukup \\
4 & $68,01-84,00$ & Baik \\
5 & $84,02-100$ & Sangat Baik \\
\hline
\end{tabular}

(Sumber : Wahyuni \& Nurhayati, 2019)

Berikut data tanggapan responden terhadap kemandirian belajar dengan skor aktual dan skor ideal.

Tabel 4. Tanggapan Responden terhadap Kemandirian Belajar

\begin{tabular}{ccccccccccccccccccccccc}
\hline & 1 & 2 & 3 & 4 & 5 & 6 & 7 & 8 & 9 & 10 & 11 & 12 & 13 & 14 & 15 & 16 & 17 & 18 & 19 & 20 & Total \\
\hline $\begin{array}{c}\text { Skor } \\
\text { Aktual }\end{array}$ & 28 & 29 & 28 & 37 & 33 & 38 & 33 & 41 & 26 & 26 & 24 & 27 & 26 & 17 & 23 & 29 & 23 & 31 & 26 & 20 & 565 \\
$\begin{array}{c}\text { Skor } \\
\text { Ideal }\end{array}$ & 44 & 44 & 44 & 44 & 44 & 44 & 44 & 44 & 44 & 44 & 44 & 44 & 44 & 44 & 44 & 44 & 44 & 44 & 44 & 44 & 880 \\
\hline
\end{tabular}

(Sumber: Hasil Penelitian 2020)

$$
\begin{aligned}
\text { Persentase skor aktual } & =\frac{\text { skor aktual }}{\text { skor ideal }} \times 100 \% \\
& =\frac{565}{880} \times 100 \%=64 \%
\end{aligned}
$$


Berdasarkan perhitungan dari Tabel 4., maka dapat diketahui bahwa persentase tanggapan responden terhadap kemandirian belajar mahasiswa melalui pengajaran blended learning adalah 64,0\%, dari hasil tersebut maka tanggapan responden berada pada kriteria cukup yaitu pada rentang $52,01 \%-68,00 \%$. Setelah itu peneliti mengadakan wawancara terhadap subjek penelitian. Wawancara dilakukan setelah subjek penelitian menyelesaikan pengisian angket. Pelaksanaan wawancara dilaksanakan untuk memastikan adanya tanggapan atau pendapat mahasiswa tentang kemandirian belajar melalui pengajaran blended learning pada mata kuliah kalkulus lanjut yang sedang mereka jalani di masa pandemi Covid-19.

\section{PEMBAHASAN}

Berdasarkan hasil penelitian yang telah diperoleh dapat diketahui persentase tanggapan responden terhadap kemandirian belajar mahasiswa melalui pengajaran blended learning adalah 64,0\%. Sejalan dengan penelitian Wahyuni \& Nurhayati (2019) menunjukkan bahwa tanggapan responden terhadap kemandirian belajar mahasiswa melalui pengajaran blended learning pada mata kuliah matematika ekonomi sebesar $77,0 \%$, dari hasil tersebut maka tanggapan responden berada pada kriteria baik, dengan rentang 68,01\% 84,00\%. Pardede (2019) mengatakan bahwa persepsi peserta didik tentang blended learning adalah positif dimana peserta didik menghargai pembelajaran menggunakan platform online tidak hanya karena menawarkan kenyamanan, fleksibilitas, dan akses langsung tetapi juga meningkatkan keterlibatan dan kemandirian mereka dan mengembangkan keterampilan literasi informasi dan teknis. Carter, Rice, Yang, \& Jackson (2020) mengungkapkan bahwa dengan pembelajaran seperti ini banyak memberikan informasi berkaitan dengan informasi kognisi dan membantu pengajar dan mahasiswa dalam mengembangkan strategi proses belajar mengajar secara mandiri. Mahasiswa dituntut untuk banyak mencari informasi berkaitan dengan pembelajaran kalkulus lanjut sedangkan pengajar yaitu dosen, berupaya semaksimal mungkin mengembangkan bahan ajarnya untuk dapat menjelaskan proses belajar secara mandiri.

Setelah itu peneliti mengadakan wawancara terhadap subjek penelitian. Wawancara dilakukan setelah subjek penelitian menyelesaikan pengisian angket. Pelaksanaan wawancara dilaksanakan untuk memastikan adanya tanggapan mahasiswa tentang kemandirian belajar melalui blended learning pada mata kuliah kalkulus lanjut. Dalam hasil penelitian Fitriasari, Tanzimah, \& Sari (2018) menunjukkan bahwa peningkatan KBM yang mendapatkan perlakuan blended learning tidak lebih baik daripada mahasiswa yang mendapatkan pembelajaran konvensional. Penelitian ini sejalan dengan temuan peneliti ketika mewawancarai responden dimana mereka merasa tidak efektif dimana mahasiswa lebih menyukai pembelajaran di kelas dan terdapat kendala beberapa faktor.

Berikut wawancara dengan mahasiswa R1.

$\mathrm{P} \quad$ : Bagaimana menurut Anda pembelajaran Kalkulus Lanjut melalui e-learning dan tatap muka yang saat ini Anda lakukan?

R1 : Kurang efektif menurut saya pribadi.

Dan ketika mewawancarai responden lain yaitu mahasiswa R11:

P : : Bagaimana menurut Anda pembelajaran Kalkulus Lanjut melalui e-learning dan tatap muka yang saat ini Anda lakukan?

R11 : Cukup berjalan dengan lancar namun ya gitu karena menggunakan internet jadi kendalanya paling ketersediaan paket internet sama jaringan. 
Namun dalam wawancara lebih lanjut beberapa responden juga mengungkapkan pembelajaran blended learning memudahkan menjalankan kemandirian belajar sebagai berikut ketika mewawancarai mahasiswa R4:

$\mathrm{P} \quad$ : Apakah fitur media e-learning dapat menyimpan bahan ajar dari dosen sehingga dapat diakses kapan saja atau hanya bisa sekali akses?

R4 : Iya. Fitur yang terdapat pada media e-learning dapat menyimpan bahan ajar yang sudah diberikan oleh dosen dan dapat diakses kapan saja

P $\quad$ : Saat diberikan tugas dan Anda mengalami kesulitan dalam pengerjaannya, apa yang akan Anda lakukan? Apakah anda menggunakan referensi belajar lain seperti Youtube, Google, atau lainnya? Kenapa Anda memilih sumber belajar tersebut?

R4 : Biasanya jika saya mengalami kesulitan saya akan berusaha mencari referensi di google terlebih dahulu seperti contoh-contoh dan bagaimana langkah-langkah pengerjaannya. Jika masih belum mengerti saya akan mencari referensi di youtube untuk lebih meyakinkan bahwa langkah-langkah pengerjaan yang saya kerjakan sudah tepat dan benar. Alasan sayamemilih sumber belajar melalui google adalah karena terdapat banyak contoh-contoh soal beserta langkah-langkahnya. Kalau sumber youtube karena kalau belajar melalui youtube saya bisa mendengarkan suara, langkah-langkah pengerjaannya yang akan dijelaskan jadi lebih mudah dipahami.

Berikut hasil wawancara menurut mahasiswa R1:

$\mathrm{P} \quad$ : Apakah fitur media e-learning dapat menyimpan bahan ajar dari dosen sehingga dapat diakses kapan saja atau hanya bisa sekali akses?

R1 : Bisa, bisa diunduh sewaktu-waktu

$\mathrm{P} \quad$ : Saat diberikan tugas dan Anda mengalami kesulitan dalam pengerjaannya, apa yang akan Anda lakukan? Apakah Anda menggunakan referensi belajar lain seperti Youtube, Google, atau lainnya? Kenapa anda memilih sumber belajar tersebut?

R1 : Kalau kesulitan ya cari di Google, karena lebih banyak referensi dan variansi model-modelnya

Hasil wawancara tersebut sejalan dengan penelitian Aslamiyah, Setyosari, \& Praherdhiono (2019) yang mengungkapkan bahwa dengan menggunakan blended learning mahasiswa lebih dimudahkan dalam proses pembelajarannya. Kemudahan yang diperoleh mahasiswa menimbulkan adanya fleksibilitas waktu bagi mahasiswa yang bekerja untuk mengakses pembelajaran yang juga sesuai dengan penelitian Wright (2017) menyatakan alasan peserta didik lebih suka pelajaran online karena kenyamanan belajar dan fleksibilitas waktu dan tempat belajar.

Dari hasil temuan dalam penelitian diperoleh beberapa informasi terkait kelebihan dan kekurangan kemandirian belajar melalui blended learning pada mata kuliah kalkulus lanjut. Kelebihannya yang pertama yaitu adanya kreatif dan inisiatif dalam memanfaatkan sumber belajar selama pembelajaran blended learning sebagaimana sesuai dengan hasil angket yang diperoleh, yaitu banyaknya responden memilih setuju pada Tabel 2. butir angket nomor 4, 6 dan 16. Adanya kreatifitas dan inisiatif ini berkaitan dengan motivasi mahasiswa dalam memanfaatkan sumber belajar. Hal inipun sejalan dengan penelitian Syarif (2012) yang mengungkapkan bahwa terjadi peningkatan motivasi dan prestasi belajar peserta didik yang signifikan akibat penerapan model blended learning akibat dari peserta didik yang memiliki motivasi tinggi atau baik membuat diri peserta didik menjadi mandiri dalam kegiatan belajarnya dirumah ataupun di sekolah yang mampu mengakses pembelajaran dimanapun dan kapanpun ingin belajar. 
Kelebihan yang kedua terlihat pada Tabel 2. butir angket nomor 8 terlihat yaitu mahasiswa memenuhi indikator membuat keputusan sendiri dengan tingginya jawaban sangat setuju jika pembelajaran melalui blended learning membuat mahasiswa lebih tepat waktu dalam pengumpulan tugas. Karena adanya batas waktu pengumpulan pada media e-learning yang tersedia oleh pihak kampus sehingga terdapat peningkatan rasa tanggung jawab dalam diri mahasiswa jika ia tidak mengumpulkan tugas tepat pada waktunya, maka ia tidak dapat mengumpulkannya lagi yang akan berdampak pada hasil belajar nya karena kurangnya nilai tugas. Hasil temuan kelebihan ini ternyata sejalan dengan penelitian Usman (2018) yang menyatakan bahwa blended learning dapat meningkatkan rasa tanggung jawab peserta didik. Pengintegrasian blended learning memperluas lingkungan pembelajaran ke dunia maya dimana batasan pembelajaran secara langsung pengajar atau tenaga pendidik ke peserta didik dapat dihilangkan (Engelbrecht, Llinares, \& Borba, 2020). Selain itu pula kebutuhan mahasiswa menjadi lebih mudah dan digabungkan dengan aspek sosial dalam kelas yang sebenarnya sehingga dapat menciptakan sistem pembelajaran yang kuat. Blended learning memberikan mahasiswa kesempatan mengembangkan pendapat mahasiswa, serta mempertimbangkan ideide baru dalam kolaborasi dengan mahasiswa lain secara daring, dan mencoba ide-ide baru tersebut dalam lingkungan yang tidak terlalu dikenal (Engelbrecht et al., 2020; Yuliati \& Saputra, 2020;Carter et al., 2020).

Kelebihan yang terakhir yaitu mahasiswa mampu mendiagnosis nilai akhir (sangat baik atau baik) yang diperoleh dengan strategi belajar masing-masing dengan adanya blended learning mengakibatkan tepat waktu dalam pengumpulan tugas dan mengikuti pembelajaran sesuai dengan arahan dosen hal ini didasari dari pernyataan angket pada tabel 2 nomor butir 5, 8, 10, 15 dan 18. Hasil ini sejalan dengan penelitian Supandi, Kusumaningsih, \& Aryanto (2016) yang mengungkapkan bahwa blended learning memberikan peningkatan pada hasil belajar siswa yang artinya mahasiswa mengalami peningkatan yang baik. Selain adanya kelebihan adapun kekurangan dalam hasil temuan penelitian kemandirian belajar melalui blended learning yaitu kurangnya kemampuan mahasiswa dalam memecahkan masalah. Kurangnya kemampuan ini sejalan dengan penelitian Sulistyani, Roza, \& Maimunah (2020) yang mengatakan bahwa jika kemandirian belajar yang dimiliki peserta didik tinggi, maka kemampuan pemecahan masalah peserta didik menjadi baik dan mampu menjadi predictor untuk mengukur kemampuan pemecahan masalah matematisnya.

\section{SIMPULAN}

Simpulan pada penelitian ini adalah persentase tanggapan mahasiswa terhadap kemandirian belajar melalui pengajaran blended learning pada mata kuliah kalkulus lanjut menunjukkan hal positif. Hal ini didukung dengan persentase tanggapan responden sebesar 64,0\% yang berada pada kriteria cukup untuk belajar mandiri. Disisi lain dengan adanya blended learning mahasiswa dengan kemandirian belajar yang baik memiliki kreatifitas dan inisiatif dalam memanfaatkan sumber belajar selama pembelajaran blended learning, mampu membuat keputusannya sendiri berkaitan dengan tugas dan tanggung jawabnya sebagai peserta didik, dan mampu mendiagnosis nilai akhir (sangat baik atau baik) yang diperoleh dengan strategi belajar masing-masing mahasiswa serta dengan adanya blended learning membuat mahasiswa tepat waktu dalam pengumpulan tugas dan mengikuti pembelajaran sesuai dengan arahan dosen.

Penelitian yang berkaitan dengan Blended Learnig, perlu adanya data tanggapan mahasiswa yang banyak terhadap angket kemandirian belajar melalui pengajaran blended learning pada mata kuliah Kalkulus Lanjut ke kriteria yang lebih baik. Untuk meningkatkan tanggapan mahasiswa tersebut perlu pertimbangan dalam pembelajaran tatap muka yang melalui aplikasi zoom ke tatap muka langsung dan pembelajaran dikelas. Selama pandemik Covid-19 telah membawa sesuatu yang baru, dari proses belajar mahasiswa dengan dosen, dan mahasiswa dengan mahasiswa. Sesuatu yang baru ini adalah sistem pembelajaran daring (online). Semua pihak yang berkaitan dengan dunia pendidikan harus mampu beradaptasi dengan cepat 
ketika dihadapkan dengan situasi seperti ini. Tantangan yang baru bagi dunia pendidikan adalah sistem monitoring dan evaluasi yang harus disusun agar pembelajaran daring terutama Blended learning ini tidak lepas dari jalur proses belajar mengajar.

\section{UCAPAN TERIMA KASIH}

Peneliti ingin menyampaikan rasa hormat dan terimakasih yang sangat mendalam kepada :

1. Tuhan Yang Maha Esa yang telah memberikan Rahmat dan Hidayahnya, sehingga peneliti selesai mengerjakan laporan penelitian dan publikasi ilmiah ini.

2. Dr. Piatur Pangaribuan, A.Md., S.H., C.L.A sebagai Rektor Universitas Balikpapan.

3. Merry K. Sipahutar, Ph. D sebagai Kepala LPPM Universitas Balikpapan.

4. Dr. Sugianto, M.M sebagai Dekan Fakultas Keguruan dan Ilmu Pendidikan Universitas Balikpapan.

5. Husnul Khotimah, S.Pd., M. Pd Ketua Program Studi Pendidikan Matematika yang telah memberikan ijin untuk penelitian pada Mahasiswa Semester VI Tahun Akademik 2019/2020.

6. Keluarga yang selalu memberikan dukungan baik moral maupun moril serta doa sehingga penelitian ini dapat berjalan dengan lancar.

\section{DAFTAR RUJUKAN}

Aslamiyah, T. Al, Setyosari, P., \& Praherdhiono, H. (2019). Blended Learning Dan Kemandirian Belajar Mahasiswa Teknologi Pendidikan. Jurnal Kajian Teknologi Pendidikan, 2(2), 109-114. https://doi.org/10.17977/um038v2i22019p109

Carter, R. A., Rice, M., Yang, S., \& Jackson, H. A. (2020). Self-regulated learning in online learning environments: strategies for remote learning. Information and Learning Science, 121(5-6), 311-319. https://doi.org/10.1108/ILS-04-2020-0114

Churiyah, M., Sholikhan, S., Filianti, F., \& Sakdiyyah, D. A. (2020). Indonesia Education Readiness Conducting Distance Learning in Covid-19 Pandemic Situation. International Journal of Multicultural and Multireligious Understanding, 7(6), 491. https://doi.org/10.18415/ijmmu.v7i6.1833

Engelbrecht, J., Llinares, S., \& Borba, M. C. (2020). Transformation of the mathematics classroom with the internet. ZDM - Mathematics Education, 52(5), 825-841. https://doi.org/10.1007/s11858-020-011764

Fandianta, F., Sanjaya, G. Y., \& Widyandana, W. (2013). Meningkatkan Pengetahuan Mahasiswa dengan Memberikan Fleksibilitas Belajar Mengajar melalui Metode Blended Learning. Jurnal Pendidikan Kedokteran Indonesia, 2(2), 1-8. https://doi.org/journal.ugm.ac.id/jpki/article/download/25178/16155

Fitriasari, P., Tanzimah, T., \& Sari, N. (2018). Kemandirian Belajar Mahasiswa Melalui Blended Learning pada Mata Kuliah Metode Numerik. Jurnal Elemen, 4(1), 1. https://doi.org/10.29408/jel.v4i1.439

Laksana, A. P., \& Hadijah, H. S. (2019). Kemandirian Belajar sebagai Determinan Hasil Belajar Siswa. Jurnal Pendidikan Manajemen Perkantoran, 4(1), 1-7. https://doi.org/10.17509/jpm.v4i1.14949

Lestari, K. E., \& Yudhanegara, M. R. (2017). Penelitian Pendidikan Matematika. (A. Anna, Ed.) (2nd ed.). Bandung: PT. Refika Aditama.

Mulianty, H. R., Hanifa, A. N., \& Sugandi, A. I. (2018). Hubungan antara Kemampuan Pemahaman Matematika dengan Kemandirian Belajar Siswa SMP yang Menggunakan Pendekatan Kontekstual. Jurnal Pembelajaran Matematika Inovatif, $\quad 1(6), \quad 1071-1077$. https://doi.org/10.1017/CBO9781107415324.004 
Ningsih, R., \& Nurrahmah, A. (2016). Pengaruh Kemandirian Belajar dan Perhatian Orang Tua Terhadap Prestasi Belajar Matematika. Formatif: Jurnal Ilmiah Pendidikan MIPA, 6(1), $73-84$. https://doi.org/10.30998/formatif.v6i1.754

Pardede, P. (2019). Pre-Service EFL Teachers' Perception of Blended Learning. JET (Journal of English Teaching), 5(1), 1-14. https://doi.org/10.33541/jet.v5i1.955

Sulistyani, D., Roza, Y., \& Maimunah, M. (2020). Hubungan Kemandirian Belajar dengan Kemampuan Pemecahan Masalah Matematis. Jurnal Pendidikan Matematika, 11(1), 1-12. https://doi.org/10.36709/jpm.vllil.9638

Supandi, S., Kusumaningsih, W., \& Aryanto, L. (2016). Keefektifan Pembelajaran Blended Learning Berbasis Kearifan Lokal pada Pembelajaran Matematika. Jurnal Pendidikan Dan Pembelajaran, 23(1), 64-69. https://doi.org/journal.um.ac.id/index.php/pendidikan-dan-pembelajaran/article/view/10154

Syahputra, D. (2017). Pengaruh Kemandirian Belajar dan Bimbingan Belajar terhadap Kemampuan Memahami Jurnal Penyesuaian pada Siswa SMA Melati Perbauangan. At-Tawassuth, 2(2), 368-388. https://doi.org/10.1017/CBO9781107415324.004

Syarif, I. (2012). Pengaruh Model Blended Learning terhadap Motivasi dan Prestasi Belajar Siswa SMK. Jurnal Pendidikan Vokasi, 2(2), 234-249. https://doi.org/10.21831/jpv.v2i2.1034

Usman, U. (2018). Komunikasi Pendidikan Berbasis Blended Learning Dalam Membentuk Kemandirian Belajar. Jurnal Jurnalisa, 4(1), 136-150. https://doi.org/10.24252/jurnalisa.v4i1.5626

Wahyuni, R., \& Nurhayati, N. (2019). Kemandirian Belajar Mahasiswa melalui Blended Learning pada Mata Kuliah Matematika Ekonomi. Jurnal Ilmiah Pendidikan Matematika AL-QALASADI, 3(2), 7681. https://doi.org/10.32505/v3i2.1203

Wright, B. M. (2017). Blended Learnings Student Perception of Face-to-Face and Online EFL Lessons. Indonesian Journal of Applied Linguistics, 7(1), 64-71. https://doi.org/10.17509/ijal.v7i1.6859

Yuliati, Y., \& Saputra, D. S. (2020). Membangun Kemandirian Belajar Mahasiswa Melalui Blended Learning Di Masa Pandemi Covid-19. Jurnal Elementaria Edukasia, 3(1), 142-149. Retrieved from http://jurnal.unma.ac.id/index.php/jee/article/view/2218 
48 Susilo \& Pancarani

JKPM (Jurnal Kajian Pendidikan Matematika) Vol.6, No.1 (2020) 